\title{
Mirela Sadowska
}

Uniwersytet Ekonomiczny we Wrocławiu, e-mail:mirela.sadowska@ue.wroc.pl

\section{SAMODZIELNOŚĆ FINANSOWA GMIN WIEJSKICH WOJEWÓDZTWA LUBUSKIEGO}

\section{FINANCIAL INDEPENDENCE OF RURAL COMMUNES OF LUBUSKIE VOIVODESHIP}

DOI: $10.15611 / \mathrm{pn} .2019 .544 .10$

JEL Classification: C38, H72

Streszczenie: Podstawą działań wszystkich jednostek samorządu terytorialnego są zasoby finansowe, które nie są adekwatne do rosnących potrzeb mieszkańców gmin. Za cele artykułu przyjęto identyfikację wskaźników wykorzystywanych przy ustalaniu samodzielności finansowej gmin oraz sformułowanie sądów wartościujących w tym zakresie w odniesieniu do 40 gmin wiejskich województwa lubuskiego. Wskaźniki wyliczono zgodnie ze wzorami proponowanymi w literaturze przedmiotu, na podstawie danych zawartych w rocznych sprawozdaniach finansowych RB-27S, RB-N i RB-PDP, a także w Banku Danych Lokalnych. Wyniki badań przedstawione w niniejszym artykule odnoszą się do problematyki ustalenia stopnia samodzielności finansowej gmin województwa lubuskiego.

Słowa kluczowe: samodzielność finansowa gmin, analiza wskaźnikowa, gminy wiejskie województwa lubuskiego, dochody własne.

Summary: The aim of the article was to identify and evaluate the indices used to establish the financial independence of municipalities and formulate judgements in this respect in relation to 40 rural communes in the Lubuskie Voivodeship. The indices were calculated in accordance with the formulas suggested in the literature, based on the data included in the annual financial statements RB-27S, RB-N and RB-PDP, as well as in the Local Data Bank. The study was concluded with a discussion of the results and the submission of proposals that could be the basis for further research into the manner of determining the financial condition of local government units in Poland.

Keywords: communes financial independence, ratio analysis, own income, rural communes of Lubuskie Voivodeship. 


\section{Wstęp}

Gminy, poza bieżącym i nieprzerwanym zaspokajaniem zbiorowych potrzeb ludności w drodze świadczenia usług powszechnie dostępnych [Ustawa z dnia 8 marca 1990, art. 9, ust. 4], stają przed koniecznością pomnażania swoich dochodów. Warunkiem realizacji zadań zarówno zleconych, jak i własnych jest posiadanie odpowiednich zasobów finansowych, dlatego samorządy, stając przed wyzwaniem sprostania oczekiwaniom obywateli (związanym przede wszystkim ze wzrostem ilości i jakości świadczonych usług publicznych), muszą uporać się z trudnościami finansowymi. Wiążą się to z jednej strony z koniecznością doprecyzowania sposobu pomiaru kondycji finansowej, a z drugiej z potrzebą określenia poziomu samodzielności finansowej gmin.

Źródła dochodów gmin określono enumeratywnie w Ustawie z dnia 13 listopada 2003 r. o dochodach jednostek samorządu terytorialnego (Dz.U. z 2018 r., poz. 1530 ze zm.), zatem możliwości gromadzenia środków i ich wydatkowania są ściśle wyznaczone przez prawo. Poza dochodami własnymi z wpływów z podatków, opłat, kar pieniężnych i grzywien określonych w odrębnych przepisach, gminy mają możliwość pozyskiwania dochodów ze sprzedaży swoich majątków, a także mają udział we wpływach z podatków dochodowych od osób fizycznych i prawnych. Prowadzone badania dowodzą, że środki pozostające w dyspozycji gmin wiejskich są znikome w relacji do intensywnie narastających potrzeb mieszkańców [Kopyściański, Rólczyński 2014, s. 62]. Znikome są również możliwości pozyskiwania środków finansowych. $Z$ jednej strony wynika to ze specyficznego charakteru małych wiejskich miejscowości, z drugiej z położenia dużych zakładów pracy.

W świetle zmian legislacyjnych, a także nakładanych na gminy nowych obowiązków oraz corocznie obniżającego się poziomu dochodów, określenie zakresu samodzielności finansowej gmin jest niezwykle ważne z punkty widzenia ich funkcjonowania i zapewnienia obywatelom dostępu do podstawowych dóbr publicznych.

Za cele artykułu przyjęto identyfikację wskaźników wykorzystywanych przy ustalaniu samodzielności finansowej gmin oraz sformułowanie sądów wartościujących w tym zakresie w odniesieniu do 40 gmin wiejskich województwa lubuskiego.

\section{Samodzielność finansowa gmin - problem definicyjny}

Punktem wyjścia w ocenie samodzielności finansowej gmin jest doprecyzowanie stosowanej nomenklatury. Zasadnicze w badaniach wydaje się określenie, czego samodzielność finansowa dotyczy. W artykułach 165-167 Konstytucji Rzeczypospolitej Polskiej [Ustawa z dnia 2 kwietnia 1997] stwierdza się, że samodzielność może być rozpatrywana jako prawo własności i prawo majątkowe, którymi jednostki samorządu terytorialnego (JST) mogą dysponować według uznania, jak również prawo do ustalania wysokości podatków i opłat w graniach legislacyjnych w celu zaspokajania potrzeb wspólnoty samorządowej. W art. 51 ust. 1 Ustawy o samorządzie 
gminnym mówi się o samodzielności w kontekście samodzielnego prowadzenia gospodarki finansowej ${ }^{1}, \mathrm{t} j$. zarządzania mieniem gminy w ramach prawa, ale zgodnie z uznaniem i potrzebami lokalnych społeczności. Uchwalona ${ }^{2}$ w Strasburgu15 października 1985 r. Karta Samorządu Terytorialnego (EKST) rozpatruje samodzielność JST pod kątem pełnej swobody działania w każdej sprawie, która nie jest wyłączona $\mathrm{z}$ ich kompetencji lub nie wchodzi w zakres kompetencji innych organów władzy [Ustawa z dnia 15 października 1985, art. 4, ust. 2]. Ten sam akt normatywny w części dotyczącej zasad finansowych społeczności lokalnych podkreśla, że w ramach narodowej polityki gospodarczej społeczności lokalne (samorządy terytorialne) mają prawo do posiadania własnych zasobów finansowych, wystarczających do wykonywania swych uprawnień, którymi mogą swobodnie dysponować. Jednocześnie wskazano, że zasoby, o których mowa, powinny być wystarczająco zróżnicowane i na tyle elastyczne, aby odpowiadać rzeczywistym kosztom związanym z wykonywaniem zadań. Tak więc zgodnie z EKST wysokość zasobów finansowych JST powinna być dostosowana do uprawnień przyznawanych im przez Konstytucję lub prawo, przy czym przynajmniej część zasobów finansowych powinna pochodzić z opłat i podatków lokalnych. Przywołane regulacje wskazują, że prawo odgrywa istotną rolę w kontrolowaniu i kreowaniu samodzielności finansowej jednostek samorządu terytorialnego. W kontekście analizy prawa administracyjnego zauważyć można wielopłaszczyznowość samodzielności, która z jednej strony znajduje swoje odzwierciedlenie w przepisach ustawy zasadniczej, z drugiej zaś wskazuje na nowy podział samodzielności: na publicznoprawną (w odniesieniu do samodzielnego wykonywania zadań publicznych) i prywatnoprawną.

W literaturze przedmiotu pojęcie samodzielności finansowej rozpatrywane jest wielowymiarowo. Poza ujęciami prawnym, politycznym i organizacyjnym, rozpatruje się je również w kontekście gospodarczym [Kozera, Głowicka-Wołoszyn, Wysocki 2016, s. 73].W opracowaniach K. Surówki [2013, s. 177] czy M. Wakuły [2005, s. 34] można znaleźć definicję samodzielności finansowej w ujęciu ekonomiczno-finansowym, przedstawiającym ją jako złożoność samodzielności dochodowej i samodzielności wydatkowej, która ma swoje uzasadnienie w wyżej cytowanych aktach prawnych. Jak zauważa J. Zaleśny [2015, s. 31], istotą samodzielności finansowej jest możliwość wykonywania zadań własnych z własnych dochodów.

Zagadnienie samodzielności finansowej, sprawia zdecydowanie większe problemy, jeśli się weźmie pod uwagę sposób jej pomiaru oraz ilość proponowanych wskaźników. W literaturze przedmiotu najmniej dyskusyjny jest udział dochodów własnych w dochodach ogółem. Relacja ta pozwala ustalić, w jakim stopniu badana jednostka jest $\mathrm{w}$ stanie samodzielnie generować dochody, ale jak podkreśla A. Zimny [2015, s.17], definicja dochodów własnych od lat budzi liczne wątpliwości. $\mathrm{Z}$ jednej strony są one postrzegane jako dochody, które gmina samodziel-

\footnotetext{
${ }^{1} \mathrm{~W}$ granicach prawa i na podstawie uchwały budżetowej gminy.

${ }^{2}$ Przyjęta przez polski system prawny w $1994 \mathrm{r}$.
} 
nie kształtuje ${ }^{3}$, z drugiej zaś, z uwagi na brak wpływu jednostki na ich wysokość, wyklucza ich udział w dochodach własnych. Jak zauważa T. Uryszka [2015, s. 9], silne powiązanie samodzielności dochodowej z wydatkową sprowadza się do samodzielności w dysponowaniu także podatkami „centralnymi” i transferami, takimi jak subwencje, co również uzasadnia zastosowanie innego wskaźnika pomiaru stopnia samodzielności finansowej, proponowanego m.in. przez J. Zaworę [2010, s.137]: ilorazu dochodów własnych powiększonych o subwencje i dochodów ogółem. Z. Ofiarski [2011, s. 93] podkreśla, że subwencje noszą znamiona pomocy państwowej, mającej charakter wyrównawczy, stanowią jednak dochód gminy i mogą być w dowolny sposób wykorzystywane. Natomiast zastosowanie ich w ocenie stopnia samodzielności finansowej może mocno podnosić wskaźnik samodzielności [Kotlińska 2009, s.143] i zniekształcać otrzymane wyniki.

\section{Stopień samodzielności finansowej gmin wiejskich województwa lubuskiego}

Badaniom stopnia samodzielności finansowej poddano 40 jednostek z województwa lubuskiego. Dane pozyskano głównie z BDL, gdyż okazało się, że w 11 przypadkach brakuje dostępu do danych finansowych ${ }^{4}$.

W badaniach skupiono się na następujących wskaźnikach:

- dochody własne do dochodów ogółem,

- dochody własne pomniejszone o podatki centralne PIT i CIT do dochodów ogółem,

- dochody własne powiększone o subwencje do dochodów ogółem,

- wydatki inwestycyjne do wydatków ogółem.

Na podstawie przeprowadzonych badań (rys. 1) zauważono, że wskaźniki przyjmowały następujące wartości:

- dochody własne do dochodów ogółem: od 25\% do 89\%,

- dochody własne pomniejszone o podatki centralne PIT i CIT do dochodów ogółem: od $16 \%$ do $53 \%$,

- dochody własne powiększone o subwencje do dochodów ogółem: od 56\% do 143\%.

${ }^{3}$ Tj. uwzględnia podatki lokalne i opłaty, a także udział w podatkach państwowych, tj. PIT, CIT i dochody z majątku.

${ }^{4}$ Przeprowadzona analiza wykazała także swoistą lukę w prawie i obnażyła nieprawidłowości w stosowaniu przepisów prawnych przez jednostki samorządu terytorialnego. W art. 34 ust. 1 pkt 9 Ustawy z dnia 27 sierpnia 2009 r. o finansach publicznych ustawodawca podkreśla jawność finansów publicznych realizowaną poprzez udostępnianie corocznych sprawozdań dotyczących finansów publicznych i jednostek organizacyjnych doń należących. Ten sam artykuł w pkt 11 wskazuje również na realizację jawności poprzez podawanie do publicznej wiadomości sprawozdań z wykonania planów działalności. Niestety, jawność nie przekłada się w praktyce na pełen dostęp do informacji dotyczących finansów gmin. 30\% z 40 badanych gmin wiejskich nie publikuje sprawozdań z wykonania budżetu. Informacje przekazywane do regionalnych izb obrachunkowych podawane są do publicznej wiadomości jedynie w znikomym stopniu, co dodatkowo wiązało się z utrudnieniami w dostępie do informacji o zarządzanych przez JST finansach publicznych, a tym samym utrudniało prowadzenie badań nad samodzielnością finansową. 


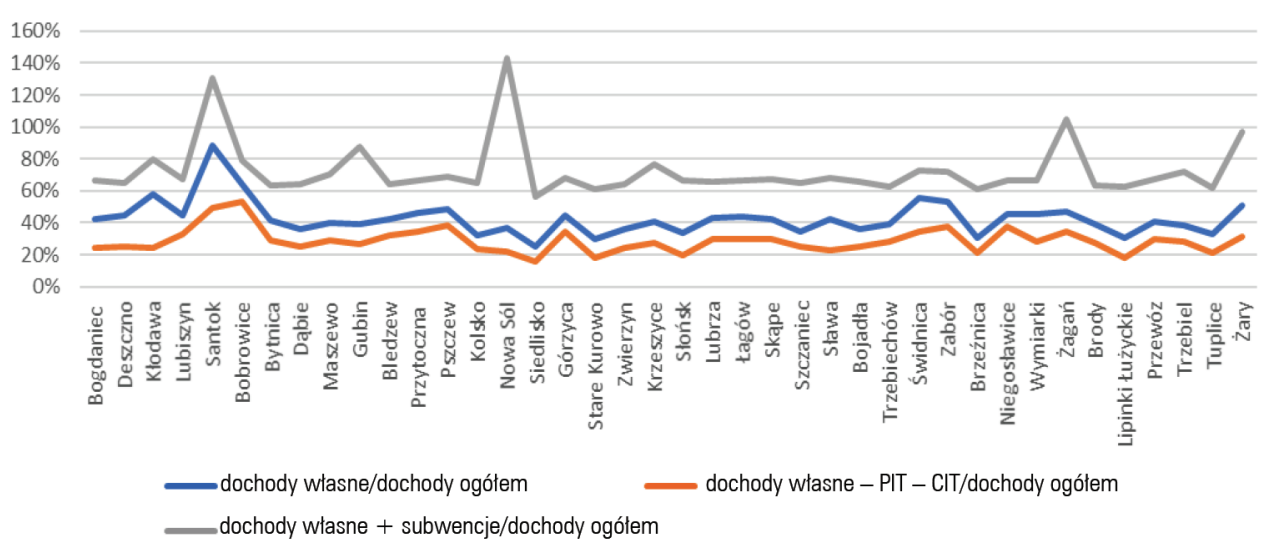

Rys. 1. Samodzielność finansowa gmin wiejskich (analiza wskaźnikowa)

Źródło: opracowanie własne na podstawie przeprowadzonej analizy wskaźnikowej.

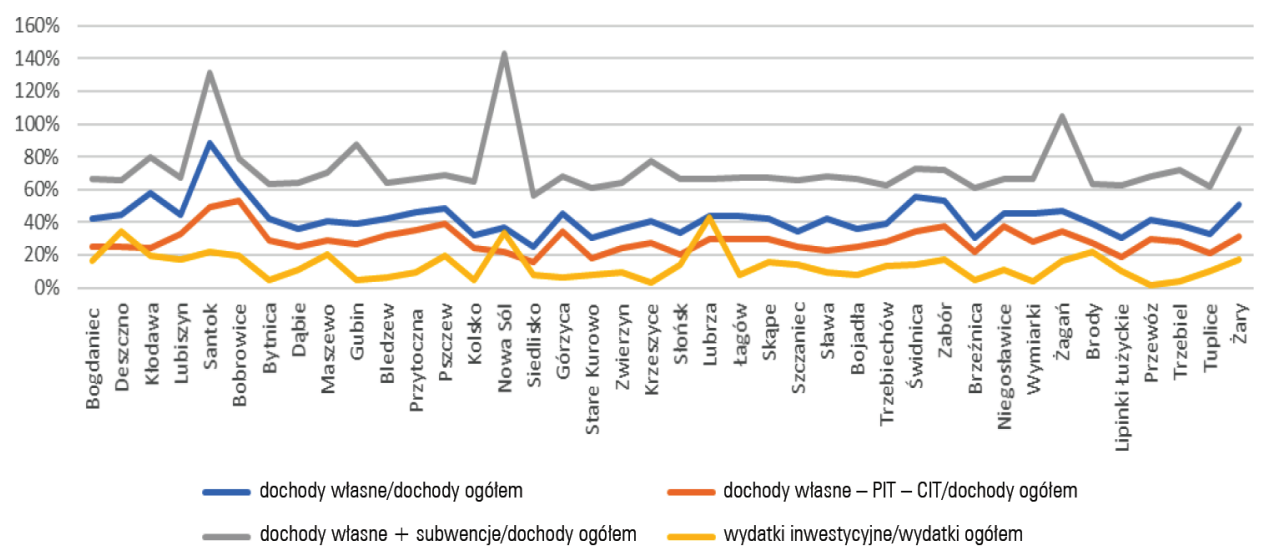

Rys. 2. Wydatki inwestycyjne a wydatki ogółem i dochody gmin

Źródło: opracowanie własne na podstawie przeprowadzonej analizy wskaźnikowej.

Stwierdzono, że gminy o najwyższym stopniu samodzielności finansowej, takie jak Santok, Żary czy Bobrowice, niezależnie, w którym wariancie są analizowane, jedynie nieznacznie zmieniają swoje położenie względem pozostałych jednostek badanych w ramach danej grupy. Wyjątkiem jest gmina Nowa Sól, która osiąga najwyższe wartości wskaźnika dochodów powiększonych o subwencje $(143 \%)^{5}$ i jedne

${ }^{5}$ Zgodnie z danymi pochodzącymi z bazy BDL dochody własne wynosiły 10300 068,14 zł, subwencje 29625027 zł, natomiast dochody ogółem 27927 196,90 zł. Wskaźnik powyżej 100\% może wskazywać na błędy popełniane przez gminę podczas przygotowywania sprawozdań finansowych i nieujęcie subwencji w dochodach ogółem. Zob. www.bdl.stat.gov.pl (23.12.2018). 
z najniższych wartości wskaźnika dochodów pomniejszonego o PIT i CIT (22\%) W przypadku gmin o najniższej samodzielności finansowej, takich jak: Siedlisko, Stare Kurowo, Tuplice czy np. Lipinki Łużyckie, w każdym z trzech badanych wariantów osiągały one najniższe wartości wskaźników.

Wskaźnik wydatków inwestycyjnych do wydatków ogółem w badanej grupie zawierał się w przedziale od $2 \%$ do $43 \%$. Otrzymany wynik dodano do wykresu samodzielności finansowej gmin (rys. 2).

\section{Wnioski}

Na podstawie przeprowadzonej analizy samodzielności finansowej stwierdzono, że gminy wiejskie województwa lubuskiego charakteryzują się bardzo niskim poziomem samodzielności finansowej, oscylującym średnio w granicach $48 \%$.

Mimo że uwzględnione $\mathrm{w}$ badaniach wskaźniki finansowe osiągają wysoce zróżnicowane wartości, najlepiej opisującym samodzielność finansową gmin wydaje się wskaźnik udziału dochodów własnych w dochodach ogółem, gdyż wskazuje, w jakim stopniu badana jednostka jest w stanie samodzielnie generować dochody. Natomiast wyłączenie podatków centralnych z dochodów gmin mocno obniżyło poziom samodzielności zwłaszcza większych gmin sąsiadujących ze strefami inwestycyjnymi i przemysłowymi (przyp. Nowa Sól).

Dochody własne stanowią średnio 43\% dochodów gmin wiejskich województwa lubuskiego, a w ujęciu z subwencjami wskaźnik wzrasta średnio do $73 \%$, co z kolei może oznaczać, że subwencje poza dochodami obcymi oraz dochodami z podatków i opłat lokalnych stanowią główne źródło utrzymania gmin wiejskich. Nakłady na inwestycje w wydatkach ogółem stanowią średnio 13\%, co z pewnością nie sprzyja aktywizacji gospodarczej gmin. W przypadku analizowanych jednostek zauważono także, że wskaźnik udziału wydatków majątkowych w wydatkach ogółem ${ }^{6}$ osiągał minimalne wartości. Oznacza to, że problemem gmin wiejskich jest także przekształcanie lokalnych potencjałów w czynniki rozwojowe, a brak inwestowania dotyczy nie tylko JST, ale również sektora prywatnego.

Zaproponowana koncepcja badania poziomu samodzielności finansowej gmin wiejskich może stanowić wstęp do rozważań nad metodyką oceny poziomu samodzielności oraz nad wpływem samodzielności na rozwój gmin wiejskich.

\section{Literatura}

Brusca I., Manes Rossi F., Aversano N., 2015, Drivers for the financial condition of local government: A comparative study between Italy and Spain, Lex Localis - Journal of Local Self-Government, vol.13, no. 2.

${ }^{6}$ Mimo że zdolność do ponoszenia wydatków inwestycyjnych stanowi jedną z kluczowych miar samodzielności finansowej. 
Głowicka-Wołoszyn R., Kozera A., Wysocki F., 2017, Identyfikacja wewnętrznych uwarunkowań samodzielności finansowej gmin wiejskich województwa wielkopolskiego z wykorzystaniem biplotu, Wiadomości Statystyczne, R. LXII, nr 8(675), s. 74-84.

Kopyściański T., Rólczyński T., 2014, Analiza wskaźników opisujących sytuacje finansowa powiatów w województwie dolnoślaskim w latach 2006-2012, Wydawnictwo Uniwersytetu Ekonomicznego w Katowicach, Katowice.

Kotlińska J., 2009, Dochody własne jednostek samorządu terytorialnego w Polsce, Ruch Prawniczy, Ekonomiczny i Socjologiczny, nr 71, z. 3.

Kozera A., Głowicka-Wołoszyn R., Wysocki F., 2016, Samodzielność finansowa gmin wiejskich w woj. wielkopolskim, Wiadomości Statystyczne, z. 2.

Mrówczyńska-Kamińska A., Kucharczyk A., Średzińska J., 2011, Analiza finansowa w jednostkach samorzadu terytorialnego na przykładzie Miasta i Gminy Środa Wlkp., Zeszyty Naukowe SGGW, nr 89.

Ofiarski Z., 2011, Subwencja jako forma prawna wydatków dokonywanych z budżetu państwa, Ruch Prawniczy, Ekonomiczny i Socjologiczny, z. 3.

Surówka K., 2013, Samodzielność finansowa samorządu terytorialnego w Polsce, PWE, Warszawa.

Surówka K., 2014, Ograniczenia faktyczne samodzielności finansowej jednostek samorządu terytorialnego, Finanse Komunalne, nr 1-2.

Uryszka T., 2015, Samodzielność finansowa jednostek samorządu terytorialnego, Finanse Komunalne, nr 12.

Ustawa z dnia 2 kwietnia 1997 r. Konstytucja Rzeczypospolitej Polskiej, Dz.U. z 1997 r., poz. 483 ze zm.

Ustawa z dnia 8 marca 1990 r. o samorządzie gminnym, Dz.U z 2018 r., poz. 994 ze zm.

Ustawa z dnia 13 listopada 2003 r. o dochodach jednostek samorządu terytorialnego, Dz.U. z 2018 r., poz. $1530 \mathrm{ze}$ zm.

Ustawa z dnia 15 października 1985 r. Europejska Karta Samorządu Terytorialnego, Dz.U. z 1994 r., poz. 607.

Ustawa z dnia 27 sierpnia 2009 r. o finansach publicznych, Dz.U. z 2017 r., poz. 2077 ze zm.

Wakuła M., 2005, Samodzielność finansowa gminy: analiza porównawcza dwóch powiatów, Samorząd Terytorialny, $\mathrm{nr} 5$.

Zaleśny J., 2015, Samodzielność finansowa gminy - założenia i rezultaty, Przegląd Prawa Konstytucyjnego, nr 5 (27).

Zawora J., 2010, Samodzielność finansowa samorząów gminnych Podkarpacia, Uniwersytet Rzeszowski, Rzeszów.

Zimny A., 2015, Sytuacja finansowa jednostek samorzadu terytorialnego w Europie Środkowo-Wschodniej. Analiza porównawcza, Finanse Komunalne, nr 3. 